\title{
Biomass and Fruit Production for the Prickly Pear Cactus, Opuntia ficus-indica
}

\author{
Victor Garcia de Cortázar \\ Departamento de Ingenieria y Suelos, Facultad de Agronomía, Universidad de Chile, Casilla 1004, \\ Santiago, Chile \\ Park S. Nobel ${ }^{1}$ \\ Department of Biology and Laboratory of Biomedical and Environmental Sciences, University of \\ California, Los Angeles, CA 90024
}

Additional index words. cladode excess dry weight, photosynthetic photon flux, planting density, stem area index, storage reserves

\begin{abstract}
Productivity of irrigated prickly pear cactus [Opuntia ficus-indica (L.) Miller] was studied over 3 years in central Chile using two planting densities. A low-density planting $\left(0.25\right.$ plants $\left./ \mathrm{m}^{2}\right)$, traditionally favored for fruit production, had maximal fruit productivity in the 2 nd year $(6 \mathrm{Mg}$ dry weight/ha per year). A high-density planting (24 plants $/ \mathbf{m}^{2}$ ), which assured almost full interception of incident solar radiation, led to an extremely high shoot dryweight productivity $\left(50 \mathrm{Mg}^{-1} \cdot \mathrm{year}^{-1}\right)$ in the 2 nd year and maximal fruit productivity $\left(6 \mathrm{Mg}^{-h^{-1}} \cdot \mathrm{year}^{-1}\right)$ in the 3rd year. Cladode dry weight tended to increase with cladode surface area. However, fruit production did not occur until the dry weight per cladode exceeded the minimum dry weight for a particular cladode surface area by at least $33 \mathrm{~g}$. The year-to-year variation in fruit production apparently reflected variations in such excess dry weight and, hence, in the storage reserves of individual cladodes.
\end{abstract}

The genus Opuntia contains $\approx 180$ of the 1600 species in the Cactaceae and consists mostly of platyopuntias, meaning that the stems occur as flattened segments termed "cladodes" (Benson, 1982; Britton and Rose, 1963; Gibson and Nobel, 1986). Certain platyopuntias are commercially important, such as the prickly pear cactus (Opuntia ficus-indica), which is cultivated in more than 20 countries (Hernández Xolocotzi, 1970; Nobel, 1988; Russell and Felker, 1987). This prickly pear cactus is cultivated primarily for its fruit, but also, its young cladodes are used as a vegetable and mature ones are used as cattle forage and fodder. About 70,000 ha have been devoted to platyopuntia cultivation in Tunisia, 100,000 ha in Italy, and 300,000 ha in Brazil, in addition to large areas in Algeria, Argentina, Chile, Mexico, and South Africa (Domingues, 1963; Monjauze and Le Houérou, 1965). Because. platyopuntias exhibit Crassulacean acid metabolism (CAM) and are drought-tolerant, they can be successfully cultivated in arid and semi-arid regions, which represent about one-third of the earth's land area (Fischer and Turner, 1978; Leith and Whittaker, 1975).

Although the above-ground vegetative dry-weight productivity of $O$. ficus-indica and other platyopuntias is generally below $10 \mathrm{Mg} \cdot \mathrm{ha}^{-1} \cdot$ year $^{-1}$ they can produce $20 \mathrm{Mg} \cdot \mathrm{ha}^{-1} \cdot$ year $^{-1}$ under appropriate conditions (Griffiths, 1915; Monjauze and Le Houérou, 1965). This annual aboveground dry-weight yield is similar to that of some agronomic crops (Beadle et al., 1985; Evans, 1975; Loomis and Gerakis, 1975). Models in which the spacing between plants is varied predict that the productivity of O. ficus-indica can exceed $30 \mathrm{Mg} \cdot \mathrm{ha}^{-1} \cdot \mathrm{year}^{-1}$ when the stem area index (total area of both sides of the cladodes per unit ground area) is 4 to 6 (Garcia de Cortázar and Nobel, 1986). Recently, high-density field trials with the planted cladodes nearly

Received for publication 10 Oct. 1991. Accepted for publication 10 Feb. 1992. Supported by Fondo National de Desarrollo Cientifico y Tecnologico grant 2037-87 and by the Environmental Sciences Division of the Office of Health and Environmental Research, U.S. Dept. of Energy, contract DE-FC03-87ER60615. The cost of publishing this paper was defrayed in part by the payment of page charges. Under postal regulations, this paper therefore must be hereby marked advertisement solely to indicate this fact.

${ }^{1}$ To whom reprint requests should be addressed. touching along rows only $0.17 \mathrm{~m}$ apart have demonstrated that $O$. ficus-indica can achieve an annual aboveground productivity of $47 \mathrm{Mg} \cdot \mathrm{ha}^{-1} \cdot \mathrm{year}^{-1}$ under irrigation in Chile (Garcia de Cortázar and Nobel, 1991) and Mexico (Nobel et al., 1992). Such high dry-weight productivity exceeds that reported for all other cultivated species, except for the $\mathrm{C}_{4}$ crops Pennisetum purpureum Schumach. and Saccharum officinarum L., which can produce up to 60 to $70 \mathrm{Mg} \cdot \mathrm{ha}^{-1} \cdot \operatorname{year}^{-1}$ (Beadle et al., 1985; Evans, 1975; Loomis and Gerakis, 1975; Nobel, 1991).

Although the above-ground productivity of O. ficus-indica can be substantial for high-density plantings, partitioning of dry matter into its fruit under such conditions has not been reported. Moreover, the spacing traditionally used for prickly pear fruit production in Chile involves a low-density planting that presumably does not lead to high shoot productivity. In this regard, perennial plants, such as trees, typically divert $15 \%$ to $20 \%$ of annual productivity into reproduction, although large variations can occur from year to year (Dickson, 1991; Larcher, 1980; Laslei and Ludwig, 1985). Hence, our main objective was to determine and compare biomass partitioning into fruits and cladodes over 3 years for $O$. ficus-indica grown at a traditional low-density spacing and at high density. To help understand the allocation of biomass into fruits, the dry weight of individual cladodes was related to fruit production on those cladodes, which helped identify a critical dry weight that was necessary for fruit production.

\section{Materials and Methods}

Mature cladodes of $O$. ficus-indica, averaging $0.38 \mathrm{~m}$ long and $0.22 \mathrm{~m}$ wide, were obtained from a commercial plantation in El Noviciado, Chile ( $\approx 20 \mathrm{~km}$ west of Santiago). They were planted on 20-22 Jan. 1988 at La Rinconada Agricultural Experiment Station, Univ. de Chile $(\approx 20 \mathrm{~km}$ southwest of Santiago; $33^{\circ} 19^{\prime} \mathrm{S}, 70^{\circ} 55^{\prime} \mathrm{W}, 500 \mathrm{~m}$ above sea level).

Two planting geometries were employed, each replicated three times in an alternating pattern in the same field direction. The geometries represented a low- and a high-density planting, using cladodes facing east-west with about one-third of their surface area below ground. The traditional low-density configuration used four cladodes, each at a corner of a square $1 \mathrm{~m}$ on a side, 
with three such squares repeated at 4-m intervals in the northsouth and east-west directions $\left(0.25\right.$ plants $/ \mathrm{m}^{2}, 2500$ plants/ha). The high-density configuration had center-to-center intervals between cladodes of $0.25 \mathrm{~m}$ along nine rows oriented north-south that were $12 \mathrm{~m}$ long and spaced $0.17 \mathrm{~m}$ apart $\left(24\right.$ plants $/ \mathrm{m}^{2}$, 240,000 plants/ha). The low-density spacing is traditionally used in central Chile to maximize fruit production by $O$. ficus-indica, and the high-density configuration leads to a high shoot biomass productivity (Garcia de Cortázar and Nobel, 1991; Nobel, 1988).

The plants were irrigated to avoid soil water limitation, and soil analysis indicated that nutrients apparently were also not limiting for growth (Garcia de Cortázar and Nobel, 1991). In July 1988, May 1989, Apr. 1990, and Apr. 1991, cladodes and fruits were harvested for morphological measurements. Cladode area was determined from paper silhouettes, and cladode or fruit dry weight was determined after drying at $65 \mathrm{C}$ in a forced-draft oven to constant weight (typically 5 days). Averaged over all harvests, the fresh weight : dry weight ratio was $13.9 \pm 0.1$ (mean $\pm \mathrm{SE}$ ) for 173 cladodes and $5.10 \pm 0.04$ for 165 fruits.

To estimate dry-matter accumulation in cladodes in the absence of fruit, cladode net $\mathrm{CO}_{2}$ exchange from the time of the previous annual fruit harvest in late summer (end of April) to fruit initiation in the winter (end of July) was estimated for the two planting densities and two observation years at La Rinconada. From 1 May to $31 \mathrm{July}$, the net $\mathrm{CO}_{2}$ uptake for a canopy of $O$. ficus-indica with a stem area index (SAI) >4.0 (appropriate for the high-density planting) under conditions of no water limitation and at ambient temperatures would be $23.2 \mathrm{~mol} \mathrm{CO}_{2}$ per $\mathrm{m}^{2}$ of ground area (Garcia de Cortázar and Nobel, 1991; Garcia de Cortázar et al., 1985). For an SAI <3.0 (appropriate for the low-density planting), total net $\mathrm{CO}_{2}$ uptake is about linear with SAI (Garcia de Cortázar and Nobel, 1986), in which case net $\mathrm{CO}_{2}$ uptake per unit ground area was estimated according to the measured SAI.

The average net photosynthesis per cladode was calculated by dividing the estimated net $\mathrm{CO}_{2}$ uptake rate per unit ground area by the number of cladodes per unit ground area, which is essentially constant from the end of summer to the next spring (Acevedo et al., 1983). To estimate the resources available for fruit initiation, the average cladode net $\mathrm{CO}_{2}$ uptake from 1 May to 31 July was converted to dry weight gain; added to the dry matter accumulated by the cladodes, based on the periodic harvests at the end of April; and then reduced by $30 \%$ to account for respiration and allocation to other organs (Nobel, 1991; Nobel et al., 1991). Once the flower buds start to differentiate in early August (Pimienta, 1990; Wessels, 1988), all net C gain was assumed to be diverted to the growth of these reproductive organs (Acevedo et al., 1983).

\section{Results and Discussion}

During the first few months after planting, new cladodes were initiated on essentially all of the basal cladodes. These new cladodes supported the growth of fruit, cladodes, or often both during the following spring, Sept. 1988. Of the 247 newly produced cladodes on the 108 plants in the low-density planting, 137 had additional organs by 3 Nov. 1988; a total of 358 fruits and 629 cladodes were produced on these new cladodes at that time. In 1989, generally only cladodes were initiated on those that were initiated in 1988.

For plants in the low-density configuration $\left(0.25\right.$ plants $\left./ \mathrm{m}^{2}\right)$, the number of cladodes per plant and, hence, per unit ground area increased steadily over 3 years of observation (Fig. 1A). The dry weight of cladodes per unit ground area increased less

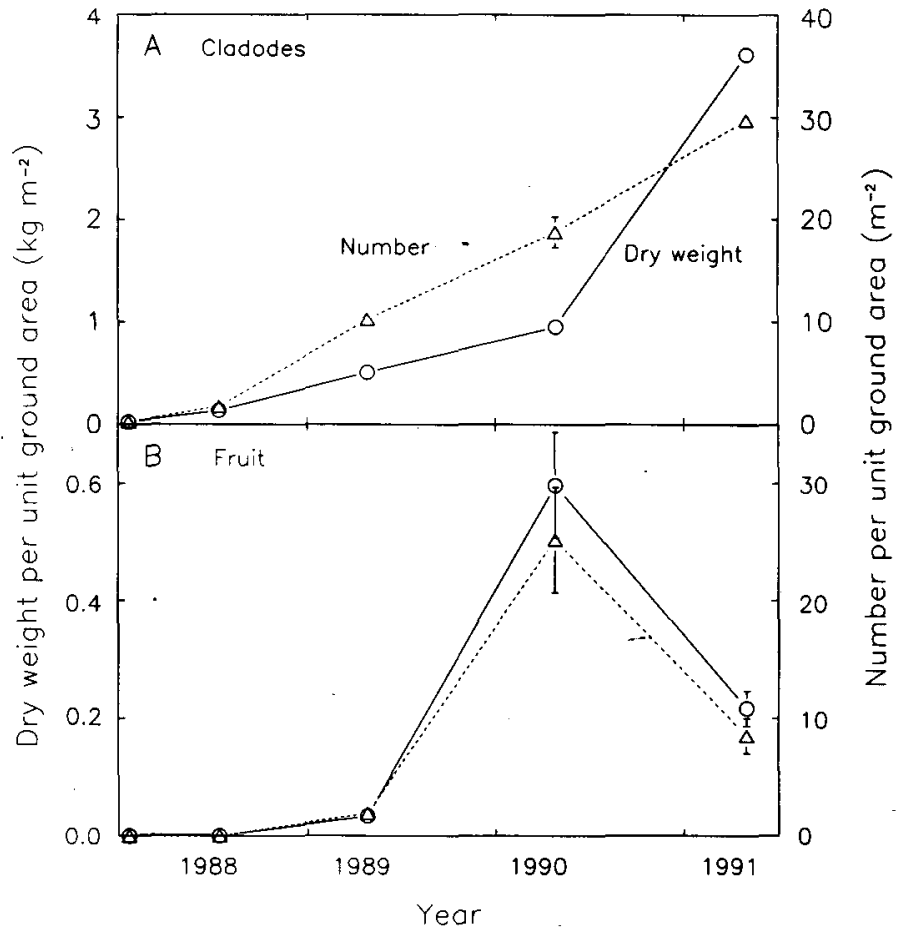

Fig. 1. Number $\left(--\Delta_{-}-\right)$and dry weight $(-\mathrm{O}-$ ) per unit ground area for cladodes (A) and fruits (B) of Opuntia ficus-indica planted at the low density traditionally used for fruit production (2500 plants/ ha). Counts were based on direct observations; dry weights are based on regression equations for cladodes of measured sizes and on harvested material for fruits. Data are expressed on a total ground area basis and are presented as mean $\pm \mathrm{SE}(\mathrm{n}=3)$, except for the Apr. 1989 and 1991 values for cladodes, for which only one measurement was made; in other cases, absence of an error bar indicates that it was smaller than the symbol.

rapidly on a percentage basis than did cladode count for the first 2 years and then more rapidly during the 3rd year. From Apr. 1990 to Apr. 1991, the average number of new cladodes per plant increased from 74 to 118 , and the average dry weight per cladode increased from 50 to 123 g. Fruit dry-weight productivity per unit ground area for the low-density planting was highest in Apr. 1990 at $0.60 \mathrm{~kg} \cdot \mathrm{m}^{-2}$, decreasing by $64 \%$ in Apr. 1991 (Fig. 1B).

For the high-density planting (24 plants $\left./ \mathrm{m}^{2}\right)$, cladode count again initially increased more rapidly on a percentage basis than did cladode dry weight, but the increases during the 3rd year were similar (Fig. 2A). The dry-weight increase per unit ground area from Apr. 1989 to Apr. 1990 was $4.94 \mathrm{~kg} \cdot \mathrm{m}^{-2} \cdot \mathrm{year}^{-1}$, $5 \%$ less in the previous year and $25 \%$ less in the succeeding year. Fruit productivity was relatively low, except during the 3rd year; fruit dry weight in Apr. 1991 was $0.55 \mathrm{~kg} \cdot \mathrm{m}^{-2}$ (Fig. 2B). Area per cladode was similar for the two planting densities, so the differences in biomass production (Figs. 1 and 2) reflected differences in the number and the dry weight of cladodes.

The production of cladode dry weight in 1990 of 4.94 $\mathrm{kg} \cdot \mathrm{m}^{-2} \cdot$ year $^{-1}$ plus the accompanying fruit productivity of 0.04 $\mathrm{kg} \cdot \mathrm{m}^{-2} \cdot$ year $^{-1}$ (Fig. 2) corresponds to $49.8 \mathrm{Mg} \cdot \mathrm{ha}^{-1} \cdot \mathrm{year}^{-1}$ for the high-density planting. Such productivity exceeds that of essentially all other cultivated species (Beadle et al., 1985; Evans, 1975; Loomis and Gerakis, 1975; Nobel, 1991). Over 3 years, the average cladode plus fruit productivity of $O$. ficus-indica was $46.5 \mathrm{Mg} \cdot \mathrm{ha}^{-1} \cdot \mathrm{year}^{-1}$. Factors contributing to the high pro- 


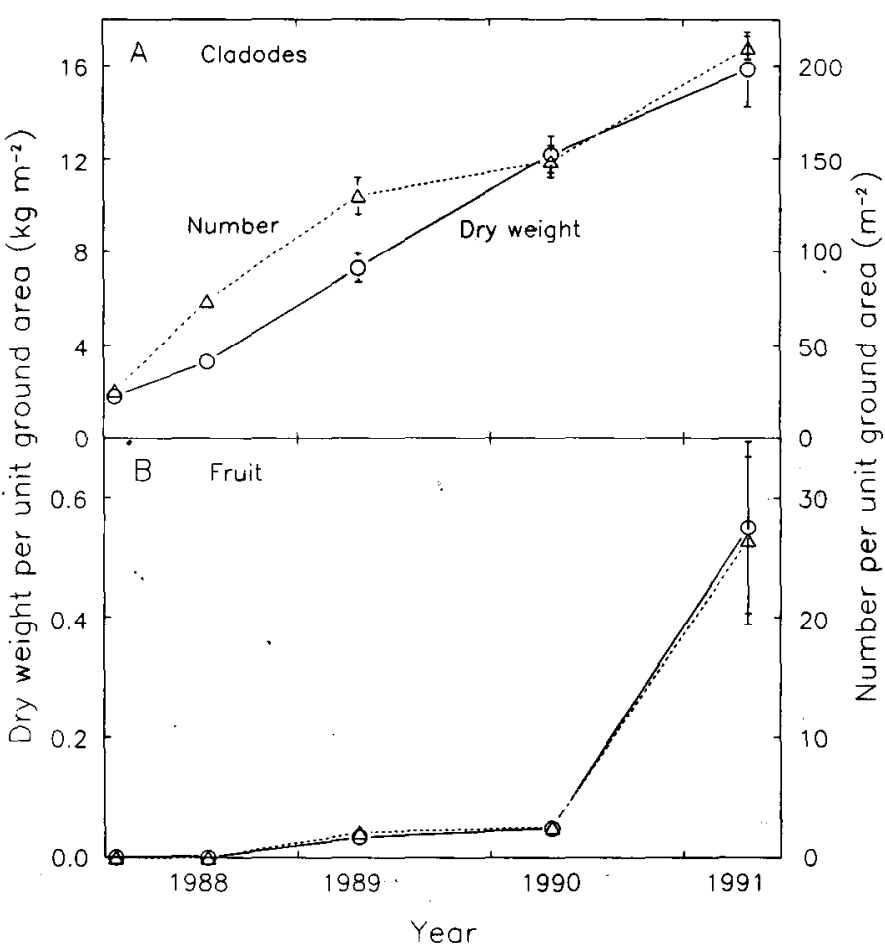

Fig. 2. Number $\left(-\Delta^{-}\right)$and dry weight $(-\mathrm{O}-)$ per unit ground area for cladodes (A) and fruits (B) of $O$. ficus-indica planted at a high density (240,000 plants/ha), leading to high productivity. To avoid fringe effects at the boundary of the plots (Garcia de Cortázar and Nobel, 1991), data from the outermost two rows on each side of the nine rows were not included. Data are presented as mean \pm $\operatorname{SE}(n=3)$, except for the Apr. 1989 and 1990 values for fruit, for which only one measurement was made.

ductivity include irrigation, a high soil fertility, and the interception of nearly all of the incident photosynthetic photon flux (PPF)by photosynthetically active tissue. Low productivities associated with CAM plants are normally the result of seasonally arid conditions and a low PPF interception per unit ground area because of a low SAI.

In terms of fruit production, maximal dry-weight productivities for the low- and high-density plantings were 0.60 and 0.55 $\mathrm{kg} \cdot \mathrm{m}^{-2} \cdot \mathrm{year}^{-1}$, respectively. Using the observed fresh weight : dry weight ratio of 5.10 for fruit, the measured fruit dry-weight production corresponds to $\approx 30 \mathrm{Mg}$ of fresh fruit/ha per year, which is a high yield (Pimienta, 1990; Wessels, 1988). Also on a fresh-weight basis, the total productivity of fruits plus cladodes averaged $630 \mathrm{Mg} \cdot \mathrm{ha}^{-1} \cdot \mathrm{year}^{-1}$ for the high-density planting over the three years of observation, again a very high yield.

Approximately equal numbers of cladodes of various sizes were harvested at four times over the three years and their dry weights were determined (Fig. 3). As the cladode surface area increased, the dry weight tended to increase at a faster rate. Also, the lower envelope, which indicates the minimum dry weight for a particular area, increased as the cladode surface area increased (Fig. 3). The curvilinear relationships indicate that increases in cladode thickness and in lignification associated with secondary growth require assimilate investment. Increasing cladode thickness is especially evident for the larger cladodes, which act as supporting structures and eventually (in 5 to 10 years) will be transformed into trunks.

Small developing cladodes up to $0.02 \mathrm{~m}^{2}$ in surface area

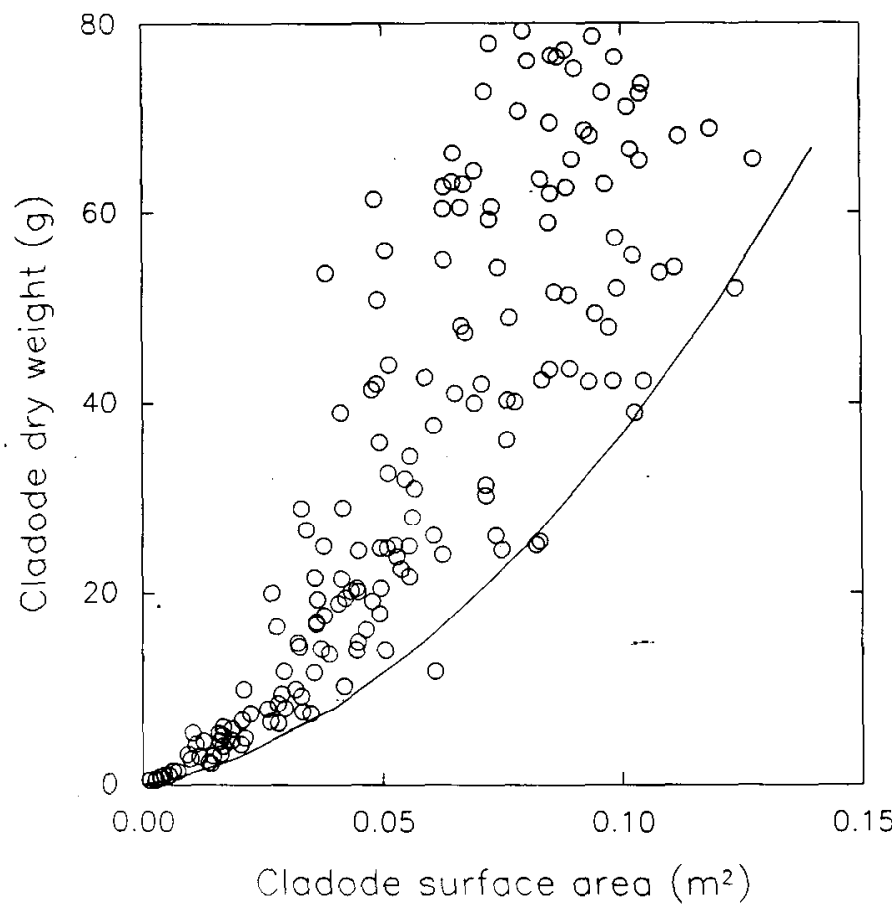

Fig. 3. Relationship between total cladode surface area (both sides) and cladode dry weight. Data are from a total of 173 cladodes harvested on 12 July 1988, 7 May 1989, 6 Apr. 1990, and 25 Apr. 1991. The regression line indicating the envelope for the minimum dry weight at a particular cladode area is: $\mathrm{DW}=88.3 \mathrm{~A}+2779$ $\mathrm{A}^{2}\left(r^{2}=0.99\right)$, where DW is the cladode dry weight in grams and $\mathrm{A}$ is its surface area in square meters; the regression line goes through the origin, as a cladode with no surface area has no dry weight.

showed little absolute variability in dry weight over the minimum for a particular area, indicating that most of the resources that they obtained from the underlying cladodes or their own photosynthesis was used for growth. Larger cladodes showed more scatter, up to $\approx 50 \mathrm{~g}$ above the minimum dry weight for average-sized cladodes (Fig. 3). Reversible excesses of dry matter above some minimum value are typical of plant structures serving as intermediate sinks for assimilates. For instance, $20 \%$ reductions in dry weight for stems of cereals are commonly observed between flowering and grain filling (Evans, 1975; Evans and Wardlaw, 1976), indicating the presence of remobilizable resources in the stems. Indeed, soluble sugars and nonstructural polysaccharides constitute $10 \%$ to $20 \%$ of the dry weight of O. ficus-indica (Nerd and Nobel, 1991).

Fruiting occurred when the cladode dry weight above the minimum value for a particular cladode surface area, referred to as "cladode excess dry weight," exceeded 33 g (Fig. 4). The abrupt switch from no fruit to up to nine fruits per cladode suggests that some signal, presumably hormonal, induces flower formation. In any case, an estimation of excess dry weight can be a good indicator of fruiting potential for a cladode. Above $\approx 100 \mathrm{~g}$ of excess dry weight per cladode, the number of fruits decreased (Fig. 4), apparently because such cladodes have undergone appreciable secondary growth and have lost the capability for producing fruits (Pimienta, 1990).

The cladode excess dry weight of $33 \mathrm{~g} / \mathrm{cladode}$ required for producing fruit (Fig. 4) is consistent with the year-to-year variations in fruit productivity for $O$. ficus-indica (Figs. 1B and 2B), as interpreted by the estimated excess dry weight per cladode above the minimum value for a particular surface area (Fig. 3) for the low- and high-density plantings (Table 1). In 


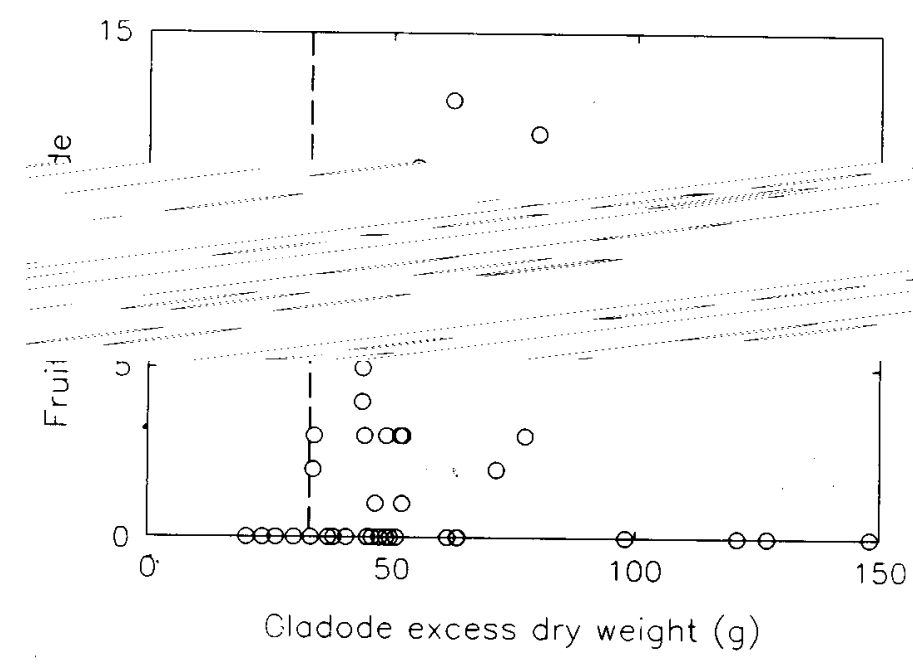

Fig. 4. Cladode dry weight in excess of the minimum dry weight for its area vs. the number of fruits on that cladode. Minimum dry weight for each cladode was determined from Fig. 3 for 45 cladodes harvested on 3 Oct. 1990. The vertical dashed line indicates the minimum cladode excess dry weight of $33 \mathrm{~g}$.

Table 1. Predicted cladode excess dry weight at the beginning of flower initiation for the two planting densities and the two years. Cladode dry weight was predicted based on data from. harvests in late April and estimated net $\mathrm{CO}_{2}$ uptake from harvest to flower initiation later in that year (end of July). Excess dry weight per cladode refers to the cladode dry weight above the minimum value for cladodes with an average total surface area of $0.0747 \mathrm{~m}^{2}$ (Fig.

\begin{tabular}{lll}
\hline \hline & \multicolumn{2}{c}{ Excess dry wt/cladode $(\mathrm{g})$} \\
\cline { 2 - 3 } Planting density & 1990 & 1991 \\
\hline Low & 37.1 & 24.7 \\
High & 30.9 & 48.0 \\
\hline
\end{tabular}

particular, the low-density planting, which showed a large decrease in the number of fruits per unit ground area from 1990 to 1991 (Fig. 1B), had an accompanying decrease in the estimated cladode excess dry weight at the time of flower initiation, falling below the critical value of $33 \mathrm{~g} /$ cladode. Thus, cladodes on such plants did not accumulate enough reserves in 1990 to allow for appreciable fruit production in the next year. A cladode excess dry weight $>33 \mathrm{~g} /$ cladode (Table 1) also underlies the triggering of reproductive growth in 1991 for the high-density planting compared with the relative lack of fruit production in 1990 (Fig. 2B). Such variation between productivity levels in successive years, as observed for the fruit of $O$. ficus-indica, is common for reproduction of many perennials (Dickson, 1991; Larcher, 1980; Laslei and Ludwig, 1985). Moreover, the cladode excess dry weight above a minimum value provides a convenient index for predicting which cladodes will produce fruit, which has important practical implications.

Fruits of $O$. ficus-indica generally do not occur on shaded cladodes, so low-density plantings generally ensure substantial fruit production per plant (Pimienta, 1990; Wessels, 1988). However, fruiting can occur under high planting densities if the uppermost cladodes accumulate sufficient excess dry weight per cladode. The relatively small increase in cladode count from 1989 to 1990 for the high-density planting helped lead to the substantial excess dry weight per cladode needed for high fruit production. The decrease in fruit per cladode after the first bearing year (Pimienta, 1990) should also be considered to attain the proper balance between cladodes for fruit production and those for vegetative growth to replace the uppermost cladodes. In this regard, year-to-year variability in fruit production can be reduced by appropriate pruning. If shading of uppermost cladodes were minimized by pruning, an excess dry weight of at least $33 \mathrm{~g} /$ cladode would be more likely, thereby ensuring greater probability of having substantial fruit production every year. The requisite $\mathrm{C}$ accumulation in individual cladodes of $O$. ficusindica can be predicted (Table 1) based on its measured responses of net $\mathrm{CO}_{2}$ uptake to soil water status, temperature, and intercepted PPF (Garcia de Cortázar and Nobel, 1991; Nobel, 1988). Hence, fruit production of $O$. ficus-indica can be controlled by appropriate horticultural practices.

\section{Literature Cited}

Acevedo, E., I. Badilla, and P.S. Nobel. 1983. Water relations, diurnal acidity changes, and productivity of a cultivated cactus, Opuntia ficus-indica. Plant Physiol. 72:775-780.

Beadle, C.L., S.P. Long, S.K. Imbamba, D.O. Hall, and R.J. Olembo. 1985. Photosynthesis in relation to plant production in terrestrial environments. Tycooly Publishing, Oxford.

Benson, L. 1982. The cacti of United States and Canada. Stanford Univ. Press, Stanford, Calif.

Britton, N.L. and J.N. Rose. 1963. The Cactaceae. Dover, New York. Dickson, R.E. 1991. Assimilate distribution and storage, p. 51-86. In: A.S. Raghavendra (ed.). Physiology of trees. Wiley, New York.

Domingues, O. 1963. Orígem e introducão da palma forrageira no Nordeste. Instituto Joaquim Nabuco de Pesquisas Sociasis. Recife, Brazil.

Evans, L.T. (ed.). 1975. Crop physiology: Some case histories. Cambridge Univ. Press, Cambridge, U.K.

Evans, L.T. and I.F. Wardlaw. 1976. Comparative physiology of grain yield in cereals. Adv. Agron. 28:302-359.

Fischer, R.A. and N.C. Turner. 1978. Plant productivity in arid and semi-arid zones. Annu. Rev. Plant Physiol. 28:277-317.

Garcia de Cortázar, V., E. Acevedo, and P.S. Nobel. 1985. Modeling of PAR interception and productivity by Opuntia ficus-indica. Agr. For. Meteorol. 16:5-15.

Garcia de Cortázar, V. and P.S. Nobel. 1986. Modeling of PAR interception and productivity of a prickly pear cactus, Opuntia ficusindica L., at various spacings. Agron. J. 78:80-85.

Garcia de Cortázar, V. and P.S. Nobel. 1991. Prediction and measurement of high annual productivity for Opuntia ficus-indica. Agr. For. Meteorol. 56:261-272.

Gibson, A.C. and P.S. Nobel. 1986. The cactus primer. Harvard Univ. Press, Cambridge, Mass.

Griffiths, D. 1915. Yields of native prickly pear in southern Texas. U.S. Dept. Agr., Washington, D.C. Bul. 208.

Hernández Xolocotzi, E. 1970. Mexican experience, p. 317-343. In: H.E. Dregne (ed.). Arid lands in transition. Amer. Assn. Advancement Sci., Washington, D.C. Publ. 90.

Larcher, W. 1980. Physiological plant ecology, 2nd ed. Springer-Verlag, Berlin.

Laslei, R.J.G. and J.A. Ludwig. 1985. Fruit production by Yucca elata Engelm. (Liliaceae) in four Chihuahua Desert habitats. Southwestern Naturalist 30:321-322.

Leith, H. and R.H. Whittaker. 1975. Primary productivity in the biosphere. Ecol. Studies, vol. 14. Springer-Verlag, Berlin.

Loomis, R.S. and P.A. Gerakis. 1975. Productivity of agricultural ecosystems, p. 145-172. In: J.P. Cooper (ed.). Photosynthesis and productivity in different environments. Cambridge Univ. Press, Cambridge, U.K.

Monjauze, A. and H.N. Le Houérou. 1965. Le rôle des Opuntia dans 
l'économie agricole Nord Africaine. Bul. Ecole Nat. Supér. de Tunisi 8-9:85-164.

Nerd, A. and P.S. Nobel. 1991. Effects of drought on water relations and nonstructural carbohydrates in cladodes of Opuntia ficus-indica. Physiol. Plant. 81:495-500.

Nobel, P.S. 1988. Environmental biology of agaves and cacti. Cambridge Univ. Press, New York.

Nobel, P.S. 1991. Tansley review no. 32. Achievable productivities of certain CAM plants: Basis for high values compared with $\mathrm{C}_{3}$ and $\mathrm{C}_{4}$ plants. New Phytol. 119:183-205.

Nobel, P.S., D.M. Aim, and J. Cavelier. 1991. Growth respiration, maintenance respiration, and structural-carbon costs for roots of three desert succulents. Functional Ecol. 6:79-85.

Nobel, P.S., E. Garcia-Moya, and E. Quero. 1992. High annual productivities of certain agaves and cacti under cultivation. Plant Cell Environ. 15:329-335.

Pimienta, E. 1990. El nopal tunero. Univ. de Guadalajara, Mexico. Russell, C. and P. Felker. 1987. The prickly-pears (Opuntia spp., Cactaceae): A source of human and animal food in semiarid regions. Econ. Bot. 41:433-445.

Wessels, A.B. 1988. Spineless prickly pears. Perskor Publ., Johannesburg. 